Henning Bergenholtz, Uwe Kaufmann \& Sven Tarp*

\title{
Vore mænd i Havanna. Værkstedsrapport fra dansk-cubansk samarbejde om udarbejdelse af en genteknologisk ordbog
}

\section{Forudsætninger}

I løbet af 1993 blev der indledt et fagleksikografisk samarbejde mellem forskere i Danmark og på Cuba. Der var tre vigtige forudsætninger, for at dette samarbejde kunne komme på benene. For det første det fagleksikografiske miljø i Danmark og navnlig på Handelshøjskolen i Århus (HHA), som gennem de senere år har publiceret en lang række teoretiske artikler og samtidig produceret en række fagordbøger, der på flere punkter betegner en nyskabelse. For det andet det samarbejde, som finder sted mellem fagleksikografer på HHÅ (Henning Bergenholtz og Sven Tarp) og fagfolk fra Den Kongelige Veterinær og Landbohøjskole (KVF) - i første række Uwe Kaufmann og Bjarne Stummann - og som er blevet praktisk udmøntet i bl.a. Bergenholtz' og Kaufmanns dansk-engelsk/engelsk-danske genteknologiske ordbog. Den sidste vigtige forudsætning for det dansk-cubanske samarbejde er det terminologiske hhv. fagleksikografiske miljø, som allerede findes på Cuba, navnlig ved Center for Oversættelse og Fagterminologi (CTTE) og Center for Litteratur og Sprog (CLL), begge tilknyttet Videnskabernes Akademi i Havanna.

Under Sven Tarps deltagelse på konferencen ExpoLingua '93, der fandt sted i Havanna i april 1993, blev der optaget kontakt med Francisco Valles, leder af CTTE, og Rodolfo Alpízar, leder af CLL og Cubas mest kendte forfatter af terminologiske artikler. Senere blev kontakter-

* Henning Bergenholtz, Department of Lexicography \& Computational Linguistics

* Sven Tarp, Department of Spanish

The Aarhus School of Business

Fuglesangs Allé 4

8210 Aarhus $V(D K)$

* Uwe Kaufmann

Den Kongelige Veterinar- og Landbohøjskole

Bülowsvej 13

1870 Frederiksberg $C(D K)$ 
ne udvidet til Iván Otero Diez, projektleder på CTTE, og Francisco Planas Guiral, leder af det terminologiske arbejde på CTTE. Disse kontakter førte til, at der blev indgået en aftale om samarbejde på to planer. For det første enedes parterne om, at de i fællesskab vil udarbejde en konkret spansk-engelsk/engelsk-spansk genteknologisk ordbog, der bygger videre på konceptet for Genteknologisk Ordbog. Desuden blev man enige om, at man i fællesskab ville arbejde for at udvikle den fagleksikografiske teori, idet den danske part i første omgang skulle bidrage med sin know-how.

Med henblik på disse mål blev der afholdt en flerdages work-shop i Havanna i begyndelsen af januar 1994. På dette møde deltog som direkte medarbejdere i ordbogsprojektet:

Fra Danmark:

Uwe Kaufmann, lektor, molekylærbiolog, KVF

Henning Bergenholtz, professor i fagleksikografi, HHA

Sven Tarp, adjunkt, Spansk Institut, HHA

Fra Cuba:

Francisco Planas Guiral, terminolog, CTTE

Laura de la Rosa Marabet, biokemiker, CTTE

Nelson la Serna Torres, kemiker, CTTE

Gladys la Serna Miranda, kemiker, CTTE.

Desuden deltog som observatører: Francisco Valles (leder af CTTE), Rodolfo Alpízar (leder af CLL), Iván Otero Diez (projektleder på CTTE), samt fire andre medarbejdere fra CTTE, der arbejder på andre ordbogsprojekter.

\section{Work-shop på Videnskabernes Akademi}

\section{Hvad er fagleksikografi?}

I dette oplæg blev der foreslået en opdeling i ordbogstyper ud fra ordbøgers genuine formål: En sprogordbog er en ordbog, der ønsker at give oplysninger om sproget, en sagordbog om sagen og en encyklopædisk ordbog (af leksikografer også kaldet alordbog) både om sproget og om sagen. Men hvor det anses for hensigtsmæssigt, kan en sprogordbog udmærket give saglige informationer, og en sagordbog til- 
lige sproglige. Der påpeges, at udtrykket fagordbog bliver brugt om alle tre grundtyper, så den alt efter intenderet formål kan tilordnes hver af de tre grundtyper. Man kan i overensstemmelse med denne opdeling skelne mellem sprogleksikografi, fagleksikografi og albogsleksikografi. Leksikografi kan dog ikke blot forstås som udarbejdelse af konkrete ordbøger, men består også i leksikografers teoretiske overvejelser om og undersøgelser af ordbøger. Der kan derfor skelnes mellem ordbogsforskning hhv. metaleksikografi og praktisk leksikografi. Leksikografi bliver ikke anset som en del af lingvistikken eller det lingvistiske delområde leksikologi, da leksikografi omfatter en række arbejdsområder, som ikke indgår i lingvistikken hhv. leksikologi, f.eks. ordbogsstrukturer, overvejelser om lay-out eller om faglige sammenhæng i forbindelse med fagordbøger. Snarere kan der ses en stor overensstemmelse med terminografi (også kaldet leksikografisk terminologi). Disse udtryk kan anses for synonyme med fagleksikografi.

Dette oplæg førte til en stor diskussion om forholdet mellem fagleksikografi og terminologi. Derimod blev princippet om at producere en alordbog, der kombinerer sproglige og faglige oplysninger i samme ordbog, umiddelbart accepteret af alle.

\section{Præsentation af det foreløbige koncept}

Dette oplæg gav først og fremmest en karakteristik af den forventede brugergruppe, der vil bestå af såvel fagfolk som semifagfolk (studerende og specialister fra nabodiscipliner) og lægfolk. Brugergruppen er desuden karakteriseret ved, at den enten har engelsk eller spansk som modersmål og samtidig behersker det respektive fremmedsprog i forskellig grad. Der blev endvidere givet en karakteristik af de sproglige og faglige funktioner, som ordbogen må dække for brugere med de to modersmål. Det drejer sig om følgende:

1. Produktion på L1

2. Reception af L1

3. Produktion på L2

4. Reception af L2

5. Oversættelse L1-L2

6. Oversættelse L2-L1

7. Indføring i genteknologien 
I oplægget blev der endvidere fremført, at alle disse funktioner ikke nødvendigvis retter sig mod alle brugertyper. Således vil en faguddannet genteknolog næppe have behov for ordbogen til reception af L1tekster eller til indføring i sit fag. Derimod vil vedkommende have stor nytte af den i.f.m. reception og produktion af L2-tekster og ved oversættelse. Omvendt vil semifagfolk og lægfolk kunne bruge ordbogen ved alle de nævnte funktioner, selv om især lægfolk næppe vil give sig i kast med at producere tekster inden for et område, de ikke har forstand på.

I forlængelse af oplægget udviklede der sig en større diskussion om, hvilken eller hvilke af de opregnede funktioner der bør have hovedprioritet i det pågældende ordbogsprojekt. Der blev bragt mange synspunkter og vurderinger på bane, uden at der dog blev draget nogen endegyldig konklusion. Derimod var der enighed om, at spansk-talende brugere ville være den vigtigste målgruppe.

\section{Præsentation af cubanernes leksikografiske erfaringer.}

Francisco Planas Guiral præsenterede her de forskellige ordbogsprojekter, som medarbejdere ved CTTE enten har afsluttet eller er i gang med. De vigtigste af disse var en spansk-engelsk-fransk-tysk bioteknologisk ordbog på 7.000 lemmata, som allerede forefindes i en computer-udgave, samt en spansk-engelsk-fransk-tysk farmaceutisk ordbog på 23.000 lemmata, som er under udarbejdelse.

Med hensyn til den bioteknologiske ordbog bærer den i sin lemmaselektion præg af, at ordbogen oprindelig er opstået som en russiskspansk ordliste til oversættelse af russiske bioteknologiske tekster. Desuden er det tydeligt, at såvel lemma- som ækvivalentselektion er udført af sprogfolk alene, hvad især de tilstedeværende cubanske fagfolk gjorde opmærksom på.

CTTE har desuden udarbejdet et computerprogram til ordbøger, hvor et af principperne er, at brugerne selv kan udvide deres ordbog.

\section{Besøg på bioteknologiske institutioner.}

For at supplere vores kendskab til den cubanske parts viden inden for molekylærbiologi og genteknologi blev der arrangeret to bes $\emptyset \mathrm{g}$ på bioteknologiske institutioner. Det første besøg var på "Biotec", et informa- 
tionscenter, der bl.a. specialiserer sig i markedsanalyser for forskellige produkter. Det har hertil oprettet en database over institutioner og virksomheder, som på den ene eller anden måde arbejder inden for bioteknologi i Cuba og hele verden. Denne database var tydeligvis meget omfattende, f.eks. indeholdt den oplysninger om 96 danske institutioner og virksomheder, hvor vi konstaterede, at alle oplysningerne var korrekte.

Det næste besøg var på "Centro de Ingeniería Genética y Biotecnología", dvs. Center for Genteknologi og Bioteknologi. Centret beskæftiger i dag over 700 medarbejdere alt i alt. Arbejdet inden for bioteknologi på Cuba startede så småt i begyndelsen af 1980'erne med udsendelse af cubanske forskere til institutioner $\mathrm{i}$ andre lande, men er først virkelig bygget op inden for de sidste fire år gennem en række meget store investeringer. Centret fremstiller en række produkter såsom farmaceutica, diagnostica og biochemica, f.eks. enzymer, restriktionsnukleaser og andre produkter til molekylærbiologisk arbejde. Nogle af produkterne er baseret på genteknologiske fremstillingsmetoder. Varesortimentet består dels af helt almindelige, dels af mere specielle produkter. En enkelt vaccine mod Meningitis $B$ blev præsenteret som unik på verdensplan.

\section{Fordelingsstruktur}

Dette oplæg koncentrerede sig i første række om de forskellige måder, hvorpå man kan strukturere de sproglige og faglige oplysninger i fagordbøger, dvs. i artikler, overbliksartikler, særlige ordbogskomponenter og uden for ordbogen. Der blev lagt vægt på behovet for en udviklet henvisningsstruktur for at forbinde disse oplysninger. Herefter blev der ud fra citater af Goethe og brødrende Grimm diskuteret fordele og ulemper ved henholdsvis alfabetisk og systematisk makrostruktur i lemmalisten, idet der samtidig blev taget udgangspunkt i brugerbehov og funktioner.

Der udspandt sig herefter en meget livlig diskussion om flere spørgsmål. Der var udbredt enighed om, at den alfabetiske makrostruktur var at foretrække til det konkrete ordbogsprojekt. Der blev ligeledes opnået fuld enighed om ønskværdigheden af en faglig indledning, hvor en del af den faglige encyklopædiske viden placeres, men det skete dog først efter en længere diskussion, hvor især den cubanske side i starten gav 
udtryk for en del tvivl, fordi en sådan ordbogssektion for dem var en fuldstændig nyskabelse, som de ikke kendte fra fagordbøger.

\section{Det faglige indhold i ordbogen}

Dette oplæg omfattede følgende tre punkter:

1. En kort fagsystematisk gennemgang af molekylærbiologien.

2. En omtale af et temaafsnit om genteknologi og en diskussion af spørgsmål vedrørende genteknologi og samfund.

3. Endvidere blev det ved eksempler vist, hvordan man kan afgrænse molekylærbiologien fra overlappende naboområder som biofysik, biokemi, mikrobiologi, botanik, zoologi og genetik.

Der blev gjort opmærksom på, at denne fagsystematik og afgrænsning til naboområder ville være grundlaget for spørgsmål vedrørende selektion af tekster til tekstkorpus, lemmaselektion samt udarbejdelsen af de faglige forklaringer og den faglige indledning.

Der var ingen indvendinger mod det faglige indhold i ordbogen. Derimod var der en del diskussion af, hvorvidt den faglige indledning overhovedet skulle inkludere en diskussion af genteknologi og samfund. Det blev her klart, at den offentlige diskussion af dette spørgsmål langt fra er så udviklet i Latinamerika som i Europa. Til sidst blev der opnået enighed om at behandle problematikken i almindelighed uden at komme ind på konkret lovgivning $\mathrm{i}$ de forskellige lande. Arbejdsgruppen anmodede desuden Uwe Kaufmann om at kontakte ONUDI i Wien, Østrig, for at få oplyst, om der inden for FN-regi er diskuteret eller eventuelt opstillet forslag om regelsæt vedrørende anvendelse af genteknologiske produkter.

\section{Sproglige oplysninger i fagordbøger}

I det følgende oplæg blev der fremlagt forslag til indarbejdelse af grammatiske oplysninger til lemmata og ækvivalenter i fagordbøger, ligesom behovet for kollokationer, synonymer og antonymer blev diskuteret.

På grund af en tilfældig bemærkning opstod der en voldsom diskussion om valg af en deskriptiv eller en præskriptiv fremgangsmåde. Blandt flere cubanere var der en klar puristisk opfattelse af, at man i fagordbøger kun kan medtage spanske ord, der enten er godkendt af 
Akademiet (det vil her sige det cubanske sprogakademi), eller som i det mindste staves og udtales efter de af Akademiet fastlagte regler. Konkret gik diskussionen på det engelske låneord standard, som optræder $\mathrm{i}$ adskillige spanske fagtekster. Puristerne afviste, at et sådant ord kunne medtages i en spansk ordbog. I stedet burde det efter deres mening helt erstattes af det forspanskede estándar. Andre mente, at begge ord måtte medtages, da de optræder i konkrete fagtekster. Der blev ikke opnået enighed om fremgangsmåden på dette tidspunkt.

\section{Selektion}

Et væsentligt grundlag for lemma- og ækvivalentselektionen udgør et engelsk og et spansk tekstkorpus. Det spanske korpus er på godt 1,15 mill. tekstord og bygger på det i Danmark oprettede genteknologiske korpus (Lauridsen/Skytte 1993). Dette korpus er dog ikke anvendt i fuld udstrækning, idet tekster, der er udarbejdet af lægfolk, er frasorteret, samtidig med at der er tilføjet en række tekster fra de sidste tre års udgaver af den spanske version af "Scientific American". Det engelske korpus er på omkring 550.000 tekstord og består af det korpus, der oprindeligt var udarbejdet til Genteknologisk Ordbog samt nye tekster fra de seneste årgange af "Scientific American” og uddrag af lærebøger i immunologi.

Princippet for selektionen er, at alle fagtermer inden for ordbogens fagområde samt fællesord, der har en særlig brug eller betydning inden for dette område, medtages. Endvidere blev det foreslået og vedtaget, at der selekteredes ord tilhørende tre forskellige grupper:

Gruppe 1 ord er sådanne, hvortil der bringes forklaring.

Gruppe 2 ord har ingen forklaring, men henviser til gruppe 1 ord.

Gruppe 3 ord har hverken forklaring eller henvisning.

Opdelingen i disse tre grupper bygger på fagets systematik. Gruppe 1 ord er således centrale termer inden for molekylærbiologien. De kan også være fællesord, som har en særlig brug inden for dette felt, hvorfor de kræver en forklaring. Gruppe 2 ord er synonymer til allerede selekterede gruppe 1 ord, idet der her anvendes et bredt synonymibegreb, som også indbefatter synonymi mellem ordklasser. Endelig er gruppe 3 ord mere perifere termer, der fremfor alt medtages for at hjælpe brugeren i en oversættelsessituation. 
Selektionen af engelske lemmata sker ud fra følgende materiale:

1. Alle engelske lemmata i Genteknologisk Ordbog.

2. Den nye del af det engelske tekstkorpus.

3. Den engelsk lemmaliste i cubanernes Diccionario de Biotecnología.

4. Et udvalg af engelske lemmata i Babel et al.1989.

Den engelsk lemmaselektion på ca. 4.500 lemmata blev afsluttet under opholdet på Cuba. Den blev foretaget efter ovennævnte principper i et samarbejde mellem Uwe Kaufmann og Gladys la Serna.

Med hensyn til selektionen af ækvivalenter blev der fra vores side foreslået, at der altid kun blev selekteret og præsenteret én ækvivalent. Det medførte en stor diskussion, men til sidst blev der opnået enighed om dette princip, idet det blev besluttet, at andre mulige ækvivalenter bliver medtaget som lemmata og evt. angivet som synonymer i den modsatte sprogretning.

Efter den indledende teoretiske diskussion blev der foretaget en praktisk øvelse med selektion af spanske ækvivalenter til den engelske lemmaliste. Målet var at forene selektionskriterierne i såvel teori som praksis. Den cubanske side, der skal foretage denne ækvivalentselektion, blev delt i to grupper, hvor der i begge var såvel fagfolk som sprogfolk. Ud fra deres egen engelsk-spanske bioteknologiske ordbog skulle de kommentere ækvivalentselektionen på fire tilfældigt valgte sider, idet de skulle komme med alternative forslag, hvis de var uenige med de eksisterende ævkvialenter. De to grupper nåede forbløffende overensstemmende resultater. Samtlige gange, hvor de var uenige med de eksisterende ækvivalenter, havde begge grupper gjort sig bemærkninger, idet der dog i enkelte tilfælde var små forskelle mellem de nye ækvivalenter, som de foreslog i stedet.

På grundlag af hele denne diskussion blev det besluttet, at i alle tilfælde, hvor der var uenighed eller tvivl om de spanske ækvivalenter, skulle evt. forslag konsulteres med tekstkorpus og i sidste instans med deciderede eksperter inden for genteknologi, f.eks. medarbejdere på Center for Genteknologi og Bioteknologi i Havanna.

Den spanske lemmaselektion skal foretages af cubanerne efter følgende retningslinjer:

1. Alle ækvivalenter fra den engelsk-spanske lemmaliste medtages. (Det drejer sig her om både gruppe 1, 2 og 3 ord). 
2. Alle synonymer, som ikke blev anført som ækvivalenter i den engelsk-spanske lemmaliste, medtages ligeledes. (Det drejer sig derfor kun om gruppe 2 og 3 ord).

3. Derudover selekteres yderligere fagtermer, som er lemmatiseret i den cubanske spansk-engelske ordbog (Guiral et al. 1993).

4. Endelig foretages selektion ud fra det spanske tekstkorpus, idet der skal tilføjes sådanne genteknologiske termer, der forekommer i korpus, men ikke er medtaget efter de tre første arbejdstrin.

Der opstod her en meget omfattende diskussion om, hvorvidt engelske låneord skulle medtages i den spanske lemmaliste. Den danske side var enige om, at de skulle med. Den cubanske side var fra starten tøvende og delt i spørgsmålet. Men efter en lang diskussion af, hvordan man tilfredsstiller ordbogens brugere med henblik på de forskellige funktioner, og efter man havde kigget det spansk tekstkorpus igennem blev der opnået enighed om at medtage de engelske låneord. Et overbevisende eksempel var $D N A$, der på spansk forkortes $A D N$. I korpus var der ca. 3600 eksempler med ADN, men hele 2400 med det engelske låneord $D N A$, dvs. ca. 40 pct. For at tilgodese ikke-fagfolk, der skal bruge ordbogen til reception eller oversættelse, er det nødvendigt at medtage $D N A$, selv om dette ord ikke anbefales af Akademiet.

Cubanerne blev efter disse diskussioner igen inddelt i to grupper, der skulle foretage en spansk lemmaselektion ud fra samme materiale. Her var der en del forskelle, som blev diskuteret ord for ord, hvad der førte til nogenlunde samme kriterier.

Ud fra disse overvejelser forventes den spansk-engelske lemmaliste at ville rumme 4.000-4.500 lemmata, dvs. et tilsvarende antal som den engelsk-spanske.

Det sidste spørgsmål med hensyn til selektion var de engelske ækvivalenter til den spanske lemmaliste. Her skal der for det første tages de engelske lemmata til de spanske ævkvivalenter, der er et resultat af "vendingen" af den engelsk-spanske lemmaliste. Til de "nye" spanske lemmata skal der foretages en ækvivalentselektion efter samme principper som selektionen af spanske ækvivalenter til den engelske lemmaliste.

Sammenfattende kan man om selektionen sige, at lemmaselektionen er deskriptiv, mens ækvivalentselektionen er præskriptiv. 


\section{Byggedele}

Med hensyn til ordbogens byggedele enedes man uden ret megen diskussion om, at den nye ordbog skal rumme de samme byggedele som Genteknologisk Ordbog.

\section{Grammatiske oplysninger}

Med hensyn til grammatiske oplysninger blev det besluttet at anføre disse til både lemma og ækvivalent. Man enedes om følgende grammatiske informationer:

1. Til engelske lemmata: ordklasser, uregelmæssig flektion ved substantiver.

2. Til spanske lemmata: ordklasser, køn ved substantiver, uregelmæssig flektion, diftongering ved verber.

Med hensyn til diftongerende verber mente cubanerne først ikke, at sådanne oplysninger var nødvendige. Men på grundlag af de erfaringer, som Sven Tarp henviste til fra sin undervisning af danskere i spansk, hvor den slags verber ofte skaber problemer, og hvor de tilsvarende oplysninger så godt som altid savnes i fagordbøger, enedes man om at medtage dem, idet den nye ordbog også konciperes til engelsk-talende, dvs. brugere, der ikke har spansk som modersmål.

\section{Faglige forklaringer}

Det næste diskussionspunkt var de faglige forklaringer. Alle var på dette tidspunkt enige om, at de burde medtages på både engelsk og spansk, men her hørte enigheden op. Der blev foreslået tre forskellige måder at bringe dem på.

1. Engelske forklaringer i engelsk lemmaliste og spanske i spansk.

2. Engelske forklaringer i spansk lemmaliste og spanske i engelsk.

3. Begge forklaringer i samme lemmaliste, f.eks. i den spanske.

Der opstod her en meget lang diskussion, hvor stemningen flere gange skiftede undervejs:

Først foreslog Henning Bergenholtz løsning 2 og fik heri kun støtte fra Rodolfo Alpízar, mens alle andre var for løsning 1.

Efter frokost var stemningen vendt: Alle cubanere gik ind for løsning 2 , mens alle danskere gik ind for løsning 1. 
Herefter blev diskussionen meget konkret og gik på, hvilke af ordbogens funktioner der havde prioritet, og hvilke løsninger der gavnede de enkelte funktioner. Alle var enige om, at hvis ordbogen udelukkende skulle konciperes til oversættelsesformål, ville det eneste rigtige være at anvende løsning 2, da brugeren på denne måde kan få implicite oplysninger om sprogbrug. Også brugere, der ønsker at recipere og producere tekster på fremmedsproget, vil have størst gavn af denne fremgangsmåde. Men tages denne løsningsmodel i anvendelse, vil det ikke gavne brugere, der hovedsagelig vil anvende ordbogen til monolingvale formål såsom reception og produktion af tekster på L1 og indføring i genteknologien. Og da der blandt disse brugere kan være en del, som har meget ringe eller slet intet kendskab til fremmedsproget, vil man på denne måde udelukke disse brugere fra den samlede, tilsigtede brugergruppe. Hvis man omvendt vælger løsning 1, vil brugere, der vil foretage oversættelse eller producere på og recipere fra fremmedsproget, alle kunne finde de ønskede oplysninger ved et ekstra opslag i den modsatte lemmaliste - en operation, som de vil være i stand til, da de formodes at have et betragteligt kendskab til fremmedsproget. Hermed vil løsning 1 på den ene eller anden måde tilgodese alle brugertyper og de tilsigtede funktioner. På grundlag af denne diskussion blev man til sidst enige om løsning 1.

\section{Kollokationer}

Det næste punkt på dagsordenen var kollokationer, hvor diskussionen først gik på, hvordan man kan adskille dem fra flerordstermer, som skal lemmatiseres. Dernæst blev selektionen diskuteret ud fra et fagligt relevanskriterium. Med hensyn til den engelsk-spanske lemmaliste blev følgende fremgangsmåde besluttet:

1. Overtagelse af de engelske kollokationer i Genteknologisk Ordbog.

2. Selektion af kollokationer til de nye engelske lemmata.

3. Oversættelse af disse kollokationer til spansk under hensyntagen til korpus.

I forbindelse med sidste punkt blev der i grupper udarbejdet prøveartikler med kollokationer. Her viste der sig relativt store uenigheder, idet en puristisk sprogopfattelse må have forbehold over for tydelige anglicismer på spansk. Man enedes dog i sidste ende om en deskriptiv frem- 
gangsmåde, idet den faktiske brug i det spanske genteknologiske fagsprog, som den findes i korpusteksterne, bliver udslagsgivende.

Med hensyn til selektion af spanske kollokationer til den spanskengelske lemmaliste var der fra begyndelsen to muligheder, hvoraf kun den første er helt optimal:

1. Selektion fra det spanske tekstkorpus.

2. Vending af de engelsk-spanske kollokationer.

Efter en diskussion blev man enige om mulighed 2, dvs. vending, idet cubanernes computerkapacitet såvel som tidsforbruget talte for denne løsning, selv om alle var enige om, at den ikke er optimal.

\section{Eksempler}

Eksempler skal i den nye ordbog kun angives ved gruppe 1 ord på grund af nogle negative erfaringer med Genteknologisk Ordbog, hvor der også var eksempler ved gruppe 2 ord, som nogle brugere så har forvekslet med forklaringer.

Der var enighed om, at eksempler giver implicite oplysninger om betydning og grammatik. Spørgsmålet var imidlertid, hvilke sprog eksemplerne skal angives på og i hvilken lemmaliste de skal placeres? Efter en diskussion blev det vedtaget at bringe engelske eksempler i den spansk-engelske del for at prioritere funktionen oversættelse spanskengelsk, og fordi spansk-talende brugere forventes at udgøre den største del af ordbogens brugere. Det blev samtidig besluttet ikke at selektere og medtage spanske eksempler på grund af computerkapacitet og for at spare plads i ordbogen, der i forvejen forventes at fylde væsentligt mere end Genteknologisk Ordbog.

\section{Synonymer og antonymer}

Der var enighed om at medtage synonymer til gruppe 1 og 2 ord. Synonymerne selekteres dels i forbindelse med den spanske ækvivalentselektion i de tilfælde, hvor der må vælges mellem flere ævkvivalenter, dels fra den spanske lemmaselektion på grundlag af faglig kompetence. Præsentationen af synonymer sker ud fra et ønske om et korrekt forhold mellem deskription og præskription. Eksemplet $D N A / A D N$ på spansk illustrerer dette. Til det engelske låneord $D N A$ angives synonymet $A D N$, der anbefales af Akademiet. Til DNA, der ikke falder i spanskta- 
lende puristers smag, angives der derimod intet synonym. I de tilfælde, hvor der ikke er problemer med normering, f.eks. ved en term og dens forkortelse, angives synonymer ved begge ord.

Der var desuden enighed om også at angive antonymer til nogle lemmata. Der var herefter en kort diskussion af antonymi-begrebet inden for fagsprog, hvor modstillingen eukaryot-prokaryot blev fremdraget som et eksempel på dette, hvoraf følger, at antonymer først og fremmest giver encyklopædisk information i fagordbøger.

\section{Henvisninger}

På grundlag af ordbogens komplekse karakter var alle tilstedeværende enige om, at der måtte være et udviklet system af henvisninger for at binde de forskellige oplysninger sammen. Der var ligeledes enighed om, at henvisningerne udelukkende skal gå på det faglige indhold, dvs. ikke på de sproglige oplysninger.

Henvisninger skal aldrig gives fra gruppe 3 ord. De skal derimod altid gives fra gruppe 2 ord til gruppe 1 ord. Ved gruppe 1 ord enedes man om, at der ved hvert lemmata maksimalt kan være fire henvisninger til andre gruppe 1 ord plus en henvisning til den faglige indledning.

\section{Konklusion}

Der kendes mange ordbøger, som indledes med et klagesuk over de strabadser, som ligger bagude. Også udarbejdelse af en ordbogskonception kunne give anledning til sådanne suk, idet der under processen skal tages et meget stort antal afgørelser af vidtrækkende betydning for det påfølgende arbejde og dettes resultat. Men foreløbig kan beklagelserne udelades, idet det påbegyndte samarbejde hart vist sig at være meget lovende og også lærerigt for yderligere teoretiske overvejelser. En vigtig forudsætning herfor er uden tvivl sammensætningen af arbejdsgruppen med både leksikografiske og genteknologiske eksperter, hvor samspillet kan give den inspiration, som er nødvendig for at løse teoretiske og praktiske problemer.

De hidtige erfaringer viser, at den cubanske interesse for fagleksikografi er betydelig. Det videre samarbejde vil derfor ikke kun dreje sig om færdiggørelse af en spansk-engelsk genteknologisk ordbog, men også om deltagelse i konferencer og ledelse af workshops for latinamerikanske fagleksikografer hhv. genteknologer. 


\section{Litteratur}

Babel, Wolfgang, Monika Hagemann, Wolfgang Höhne (1989): Wörterbuch der Biotechnologie. Dictionary of Biotechnology. Frankfurt/M: Verlag Harry Deutsch.

Bergenholtz, Henning og Sven Tarp med bidrag af Grete Duvå, Ole Norling-Christensen, Anna-Lise Laursen, Hans Kristian Mikkelsen, Sandro Nielsen og Jette Pedersen (1994): Manual i fagleksikografi. Udarbejdelse af fagordbøger-problemer og lфsningsforslag. Herning: Systime.

Guiral, Francisco Planas et al. (1993): Diccionario de Biotecnología. Havanna: CTTE.

Kaufmann, Uwe/Henning Bergenholtz (1992): Genteknologisk ordbog. Dansk-engelsk/ engelsk-dansk molekylarbiologi og DNA-teknologi. København: Gad.

Kaufmann, Uwe y Henning Bergenholtz con cooperación de Bjarne Stumman, Sven Tarp, Francisco Planas Guiral, Laura de la Rosa Marabet, Nelson la Serna Torres y Gladys la Serna Miranda: Diccionario Enciclopédico de Ingeniería Genética Español-Inglés/Inglés-Español. (under forberedelse).

Lauridsen, Ole/Ingrid Skytte Andersen: Det spanske biotekniske tekstkorpus (biotek.es). In: Rapport over oprettelsen af et dansk og et tysk maskinlaesbart Tekstkorpus inden for området genteknik. København: Handelshøjskolen i København 1993:110-146. (= ARK 66). 
